\title{
経年劣化した鉛プラグ入り積層ゴム支承の 残存性能に関する実験的検証
}

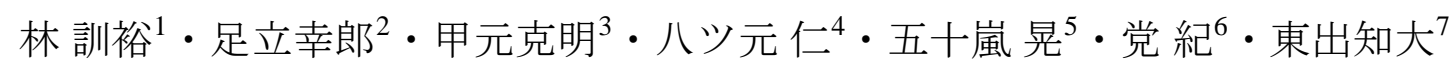

\author{
1 阪神高速道路（株）大阪管理部（干 552-0006 大阪府大阪市港区石田 3-1-25） \\ E-mail: kunihiro-hayashi@hanshin-exp.co.jp \\ 2 阪神高速道路（株）大阪管理部（干 552-0006 大阪府大阪市港区石田 3-1-25） \\ E-mail: yukio-adachi@hanshin-exp.co.jp \\ 3 阪神高速道路（株）大阪管理部（干 552-0006 大阪府大阪市港区石田 3-1-25） \\ E-mail: katsuaki-komoto@hanshin-exp.co.jp \\ 4 阪神高速道路（株）技術部（干541-0056 大阪府大阪市中央区久太郎町 4-1-3） \\ E-mail: hitoshi-yatsumoto@hanshin-exp.co.jp \\ 5 京都大学防災研究所（三611-0011 京都府宇治市五ヶ庄） \\ E-mail: igarashi.akira.7m@kyoto-u.ac.jp \\ ${ }^{6}$ 埼玉大学大学院理工学研究科（†338-8570 埼玉県さいたま市桜区下大久保 255） \\ E-mail: dangji@mail.saitama-u.ac.jp \\ 7 京都大学大学院工学研究科（干615-8540 京都府京都市西京区京都大学桂） \\ E-mail: higashide.tomohiro.85v@st.kyoto-u.ac.jp
}

\begin{abstract}
兵庫県南部地震以降, 地震力を分散させる設計や免震設計等により耐震性の向上が図られ，ゴム支承の普 及が著しい，しかしながら，長期に渡り供用中であるゴム支承に経年劣化と考えられる損傷が顕在化してい るが，支承性能へどのように影響するかが明確でないため，経過観察の状態にとどまっている，本論文では 経年劣化損傷の発生した鉛プラグ入り積層ゴム支承（LRB）の残存性能を検証するため，力学試験及び材料 試験を実施した。この結果, ゴムや鉛の経年劣化による剛性の増加及び減衰性能低下が確認された。
\end{abstract}

Key Words: lead rubber bearing, aging deterioration, remaining performance, loading test, material test

\section{1.はじめに}

1995 年に発生した兵庫県南部地震以降, 地震力分散 設計や免震設計等の設計手法により積層ゴム支承（以下， 「ゴム支承」という。）を採用し，耐震性能の向上が図 られてきた。阪神高速道路においても支承取替えを含む 而震工事や桁連結工事が盛んに行われ，ゴム支承の占め る比率は全数約 88,000 基に対して 3 割強となっている.

一方，ゴム支承の大部分を占める構成材料は天然ゴム （NR: Natural Rubber）であるが，この天然ゴムは，一般 的に耐オゾン抵抗性に乏しいという特徽を有する ${ }^{1)}$ とと もに，熱や紫外線などの環境依存性劣化，外力によるゴ
ム材料の疲労が劣化要因として挙げられる ${ }^{2), 3)}$. 寸なわ ち，ゴム支承は長期間の使用により劣化しやすいという 特性を有しているが，実際，経年に伴う損傷が顕在化し てきており，補修すべきと考えられる外観を呈している ものが存在する. しかしながら, 損傷が発生したゴム支 承の残存性能は明確ではなく, かつ効果的な補修方法が ないため，これらゴム支承の大半のものは経過観察中に あるというのが実状である.

また, 2011 年の東北地方太平洋沖地震及びその余震 において，破断を含む複数のゴム支承の損傷が報告され ている ${ }^{4,5}$. その中でも，破断したゴム支承に対して行 われた性能試験の結果より変形性能が新規製された再現 支承に比べて大きく低下しているという特筆すべき内容 
も報告されている.

これらを踏まえると，ゴム支承の劣化及びそれに伴う 損傷は普遍的に発生する現象であることから，本研究で はゴム支承の経年劣化損傷が常時ならびに地震時残存性 能に与える影響について，実際に損傷したゴム支承を用 いて力学試験及び材料試験により検証するものである.

\section{2. ゴム支承の現況と着目損傷}

\section{(1) 資産と供用年数}

阪神高速道路では 1983 年よりゴム支承が使われ始め, 現在その資産数は約 28,000 基となっている. 供用年数ご との割合は図-1 のとおりである. 供用後 11〜20 年弱を 経過しているゴム支承が大半を占めているが，これは兵 庫県南部地震以降に震災復旧工事及び而震工事（主桁連 結を含む）において鋼製支承から取替えられたものであ る.また，それ以前（20 年超）のゴム支承も 1 割弱の アセットがある.

ゴム支承の種類としては，初期はコンクリート桁での リングプレートタイプ支承が主流であったが，1990 年 頃から主桁連結に伴う水平力分散を目的とした積層タイ プが使われるようになった，震災後は前述のとおり耐震 性能向上のためのゴム支承（鉛プラグ入りタイプや高減 衰ゴムタイプなど）となっている.

\section{（2）損傷状況}

2006２012 年度の間に報告されたゴム支承の A ラン ク損傷は 811 件であり，その損傷内訳を図-2 に示す.A ランク損傷とは「機能低下があり，対策の必要がある」 場合に判定される損傷のことである.

ゴムの経年劣化による損傷と考えられる「きれつ」や 「上沓被覆ゴム破れ」，ゴム破れに伴う「鉛突出」は現 時点では 1 割弱であるが，今後経年劣化が進めば増加し ていくと予測される.ここで「きれつ」はオゾン劣化も しくは変形に伴う応力集中部（引張部）で生じた筋状の クラック，「破れ」は被覆ゴムが引張を受けて上沓の角 部において開口した状態のことであるが，両者に厳密な 区分はない. これらの事例を写真-1 に示す.

なお「鉛突出」のメカニズムとしては，以下の 2 パタ ーンが考えられる.

(1)古い鋼鈑桁はフランジ幅が狭く，支承取替えの際に ソールプレートをフランジ幅に合わせざるを得ない ため，一部の鈶プラグがソールプレートに覆蓋され ず，上載荷重が支承全体に対して不均一にかかる影 響により突出に至る.

(2)鈶プラグから支承側面までの縁端距離が小さい場合， その方向の拘束圧が相対的に小さくなることから， 地震力もしくは桁の温度伸縮に伴うせん断変形を受 けると鉛が拘束力の小さい側へ押し出され，それが 繰り返されることで最終的にはゴムを破って側面か ら突出する.

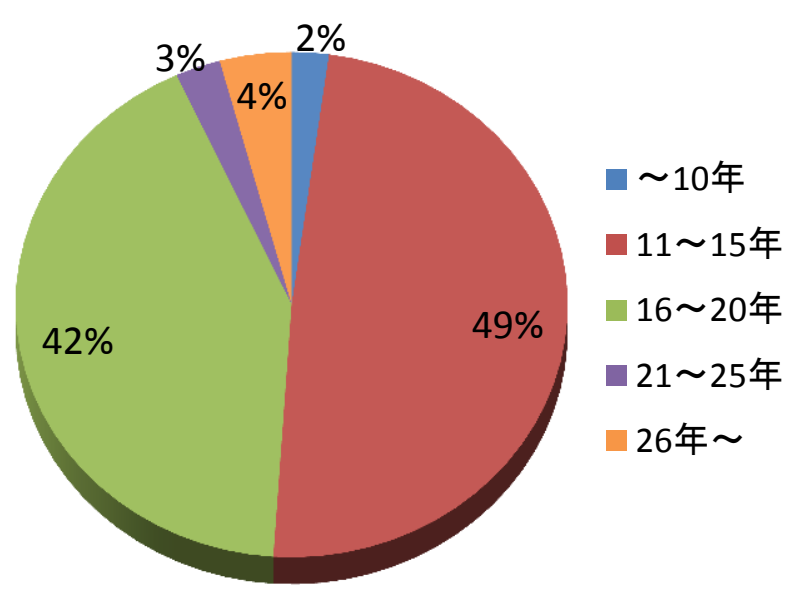

図-1 阪神高速におけるゴム支承の供用年数

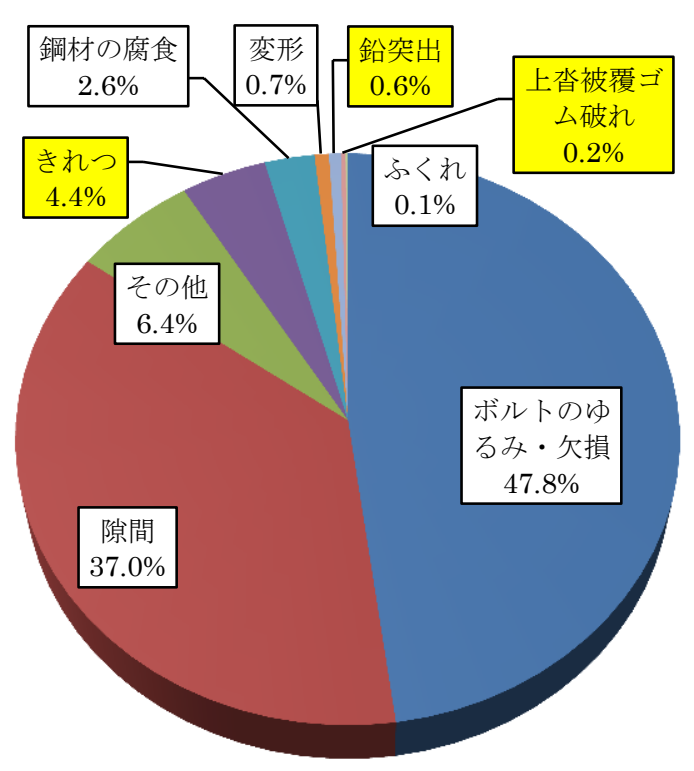

図-2＼cjkstart積層ゴム支承のAランク損傷
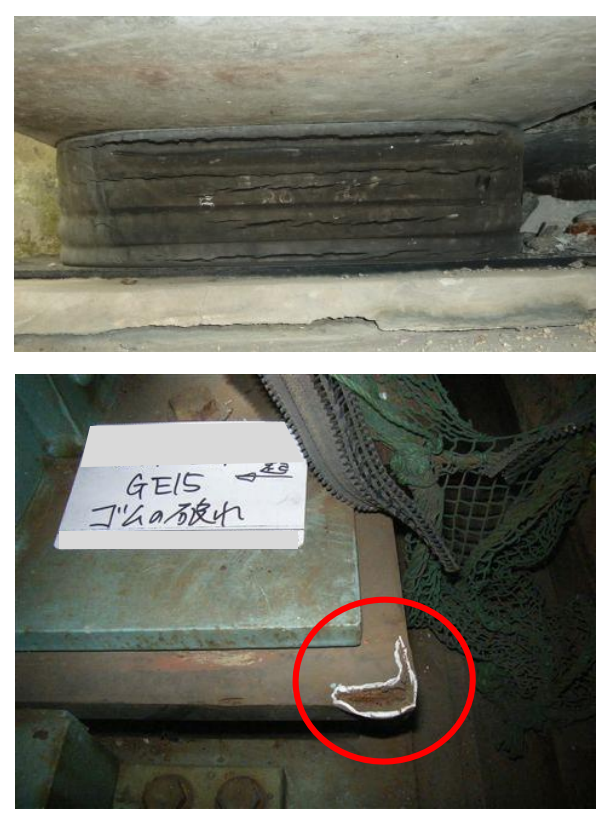

写真-1 ゴム支承損傷（上：きれつ, 下: 破れ) 
写真-2 は阪神高速 3 号神戸線で発見された支承上面 からの鉛プラグ突出であり，この損傷要因は前述の11に 該当する．この支承は既に取替えられているものの，類 似の損傷は他の支承でも報告されており，取替え以外の 補修方法がないために経過観察の点検判定となっている ものがほとんどである.

上記のような現状を鑑み，本研究においてはゴムのき れつ（破れを含む）及び鉛の突出に着目し，それらが変 形性能などの残存性能にどの程度影響しているかを検証 することとする.この理由としては，ゴムのきれつが地 震時の大変形により破断リスクが高まる可能性があるこ とや，突出による鉛の減少により設計時に想定している 地震エネルギー減衰性能が期待できないことが挙げられ る.

\section{3. 既往の研究及びその課題}

ゴム支承の経年劣化に関しては，加熱促進試験及び数 值解析による評価は行われている もものの，実際に長期 間使用されたゴム支承を用いた試験により残存性能につ いて述べられている事例は多くない. また, 現在の設計

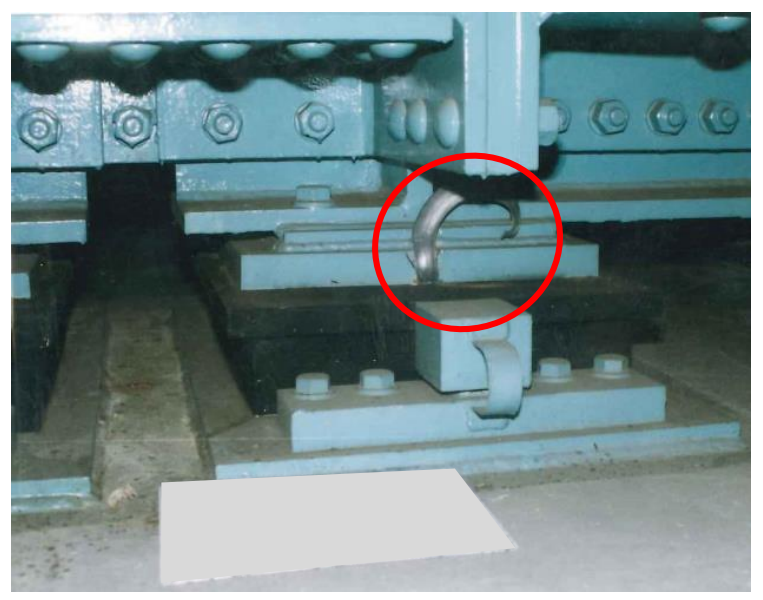

写真-2 鉛プラグの突出

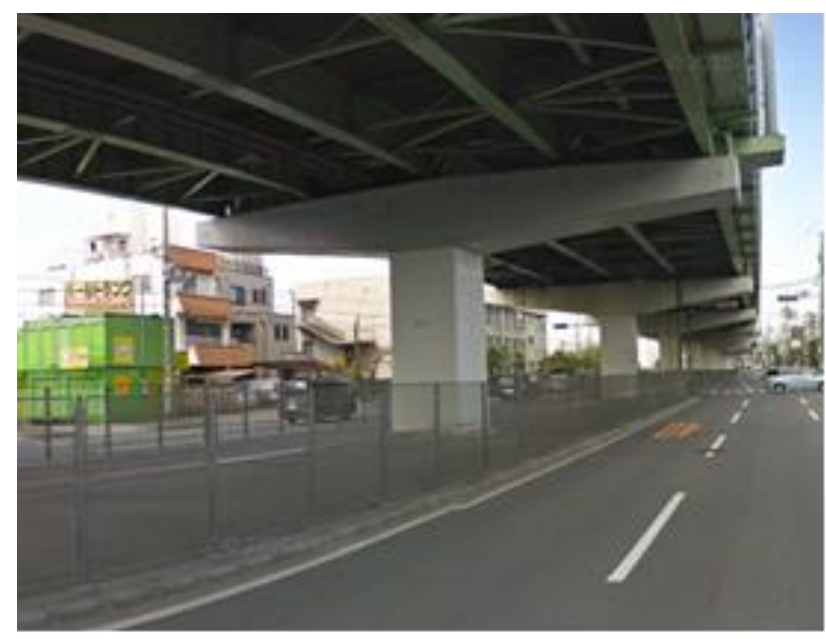

写真-3 現地状況
においてはゴム支承の経年劣化による性能低下が考慮さ れていないのが実状である.このような現状に対して， 設計における限界性能が確保されているのか把握が不可 能という課題がある.

また，東北地方太平洋沖地震では仙台東部道路及び仙 台北部道路において設置後約 10 年のゴム支承が破断す るという損傷が発生しており，その損傷ゴム支承ならび に建設当時の材料表から再現製作した支承を用いた性能 試験を行った結果，せん断変形性能が低下しているとい うことが分かった ${ }^{5}$. しかしながら，その低下が経年劣 化によるものか，地震の影響によるものなのかについて は明確に結論づけられてはいない.

一方，鉛プラグ入り積層ゴム支承（LRB: Lead Rubber Bearing）に使用される純鉛については，機械的性質がほ ぼ自明の材料であり，一般に降伏による疲労が進行しに くいという特徴からほとんど研究対象として取り上げら れていない. しかしながら, 先の東北地方太平洋沖地震 において，建築用の免震鉛ダンパーにきれつが生じてい る7など，想定していなかった損傷が明らかになってい る. 現時点では鉛の経年劣化メカニズムは不明であるこ とや供用中ゴム支承内部の鉛プラグの状況は把握不能で あることから, 設計上求められる減衰性能を有するか確 認できないという課題がある.

\section{4. 性能確認対象支承}

本研究において残存性能試験を実施するのは，阪神高 速15号堺線の堺P181橋脚のLRBである. 当該支承は，残 存性能への影響が大きいと考えられる鉛プラグの突出損 傷が発生している. 現地状況を写真-3，上下部構造概要 を図-3に示す.

建設当初（1970年竣工）は単純林及び鋼製支承であっ たが，1995年に主桁連結化による水平力分散のため支承 取替えが行われている. なお，当該箇所は連結桁（11径

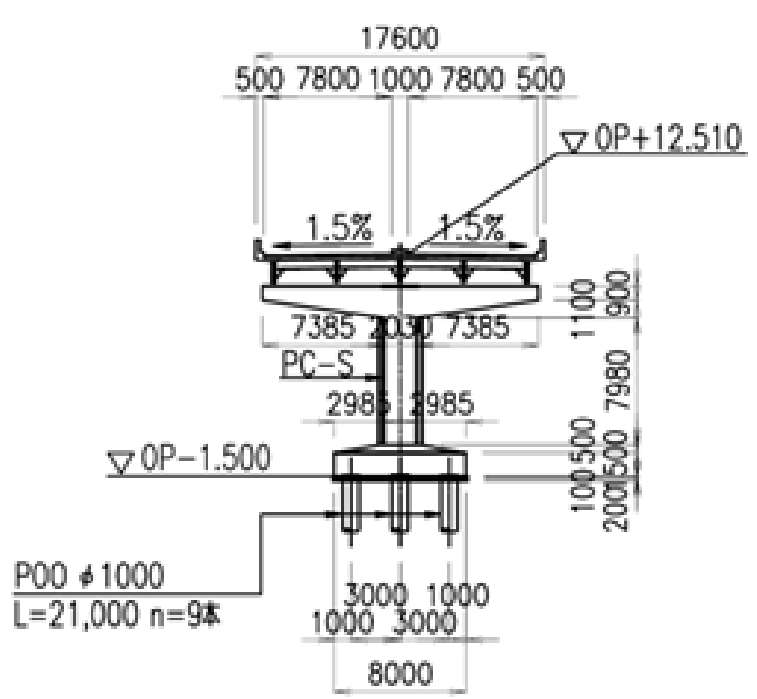

図-3 上下部構造概要図 
間）の端支点部に位置している．取替え後のゴム支承は 図-4に示寸構造図のとおり, 天然ゴム5層の積層構造で ある。

ゴムの平面寸法は $350 \mathrm{~mm} \times 550 \mathrm{~mm}$, 総厚は $14 \mathrm{~mm} \times 5$ 層 $=70 \mathrm{~mm}$, 形状係数は一次が $\mathrm{S}_{1}=6.87$, 二次が $\mathrm{S}_{2}=4.71$ であり, 地震エネルギー減衰を目的とする鉛プラグ（ $\phi 55 \mathrm{~mm} ） 4$ 本が菱形配置されている. なお, 設計は1990年道路橋示 方書ならびに1991年道路橋支承便覧に基づき，当時の地 震時許容せん断ひずみ $175 \%$ に対して設計され，試験值 を満足している.

損傷内容は写真-4に示すように，鉛プラグが支承の橋 軸方向に面した側面から突出している．第2章(2)で述心゙ た鉛突出のパターンのうち(2)該当すると考えられ，鉛 が内部より押し出されたことによりゴムが破れた（きれ つ長 $\mathrm{L}=100 \mathrm{~mm}$ ）ものである. 点検時に鉛の突出量は測 定していないが，損傷位置は上下鋼鈑に近い箇所に見ら れ，ここはせん断変形による引張や圧縮を受けやすい箇 所でもある.

過去の点検履歴より損傷は2005年（取替え後約10年） に側面ふくれが，2008年の点検て鉛突出の損傷が報告さ れていることから，徐々に進行しているものと考えられ る。なお，堺 $\mathrm{P} 181$ 橋脚では同一支承線上に5 基あり，全 てほぼ同様な損傷状況である. 参考までにゴム表面に見 られる塗膜は桁の塗装塗替工事の際に施されたものであ り, 本来は不要のものである.

\section{5. 残存性能確認試験}

\section{(1) 力学試験}

経年劣化後の地震時及び常時残存性能を確認寸ること を目的として力学試験を実施した. 表-1 に示寸試験プ ロトコルは阪神高速道路の共通仕様書 8)におけるゴム支 承の検查項目を参照しており，供用中においても保持さ れていることが望ましい重要な性能である.

上載荷重は全ケースで死荷重反力相当とし, 実橋から の回収品（以下，「劣化支承」という。）及び新規製作 品（以下，「リファレンス支承」という。）に対してそ れぞれ実施した。 なお，リファレンス支承は当時の材料 表に基づき再現製作したものである. 前述のとおり水平 せん断ひずみ $175 \%$ として設計されており，当時の設計 值は等価剛性 $2.08 \mathrm{kN} / \mathrm{mm}$ ，等価減衰定数 $18 \%$ である。

試験は図-5に示寸載荷装置を用いた。試験体の上側は 鉛直方向と回転が拘束され，水平方向の夕に移動するリ ンク機構の横梁を介し，2,000kNのアクチュエータにて 橋軸方向の水平せん断変形を与える. 同時に, 下側は水 平方向の移動がストッパーで拘束される載荷台に固定し， 載荷台を支える4本の $750 \mathrm{kN}$ 油圧ジャッキにより，死荷 重反力相当の約 $500 \mathrm{kN} の$ 鋁直方向荷重を試験体に与える. 地震時残存性能確認試験として, L1 地震, L2 地震, 終局限界の 3 ケースを実施した. 地震時試験での供試体

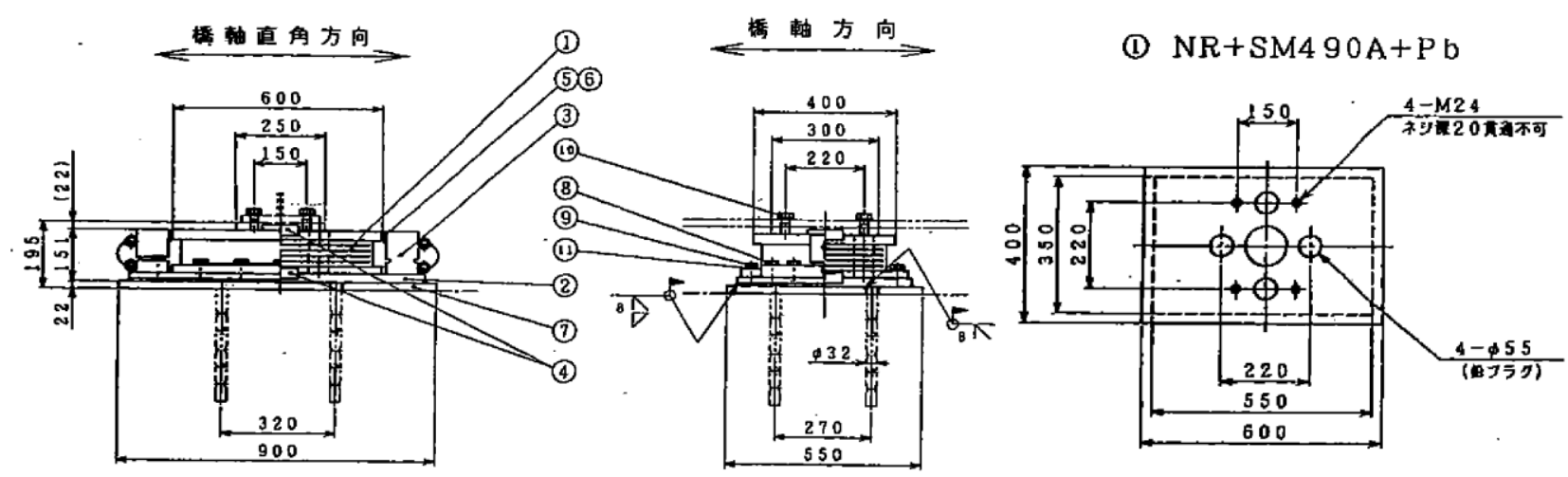

図-4 支承構造図
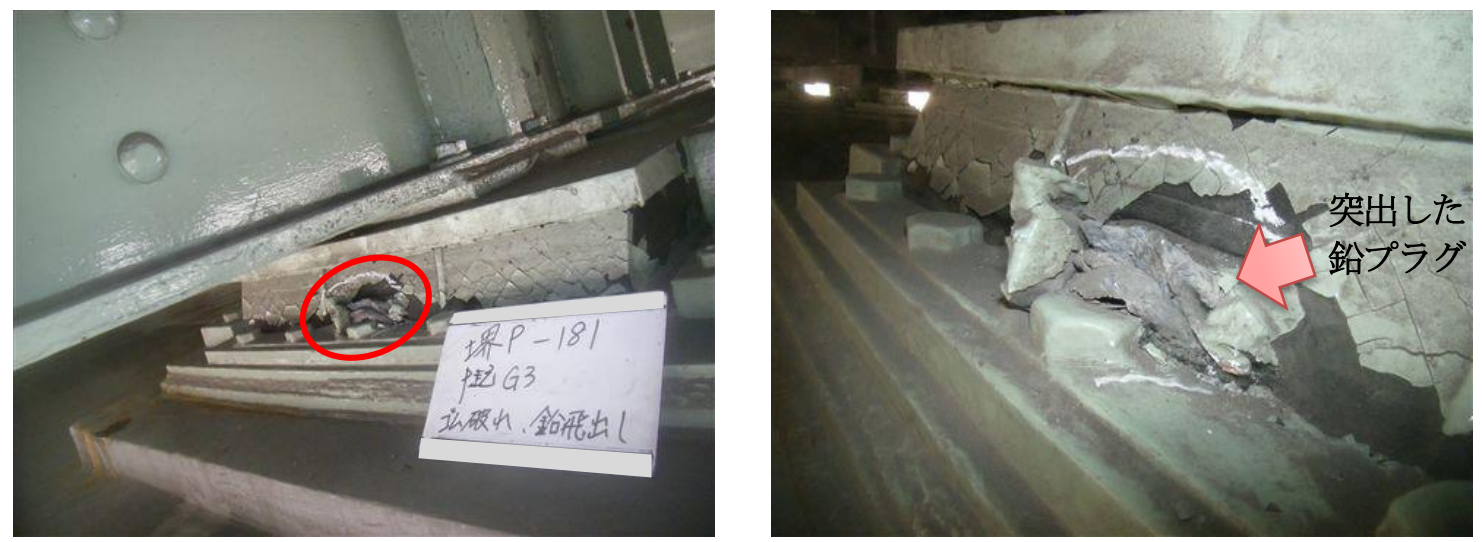

写真-4 損傷状況（左 : 全景, 右 : 損傷部拡大) 
表-1 力学試験のプロトコル

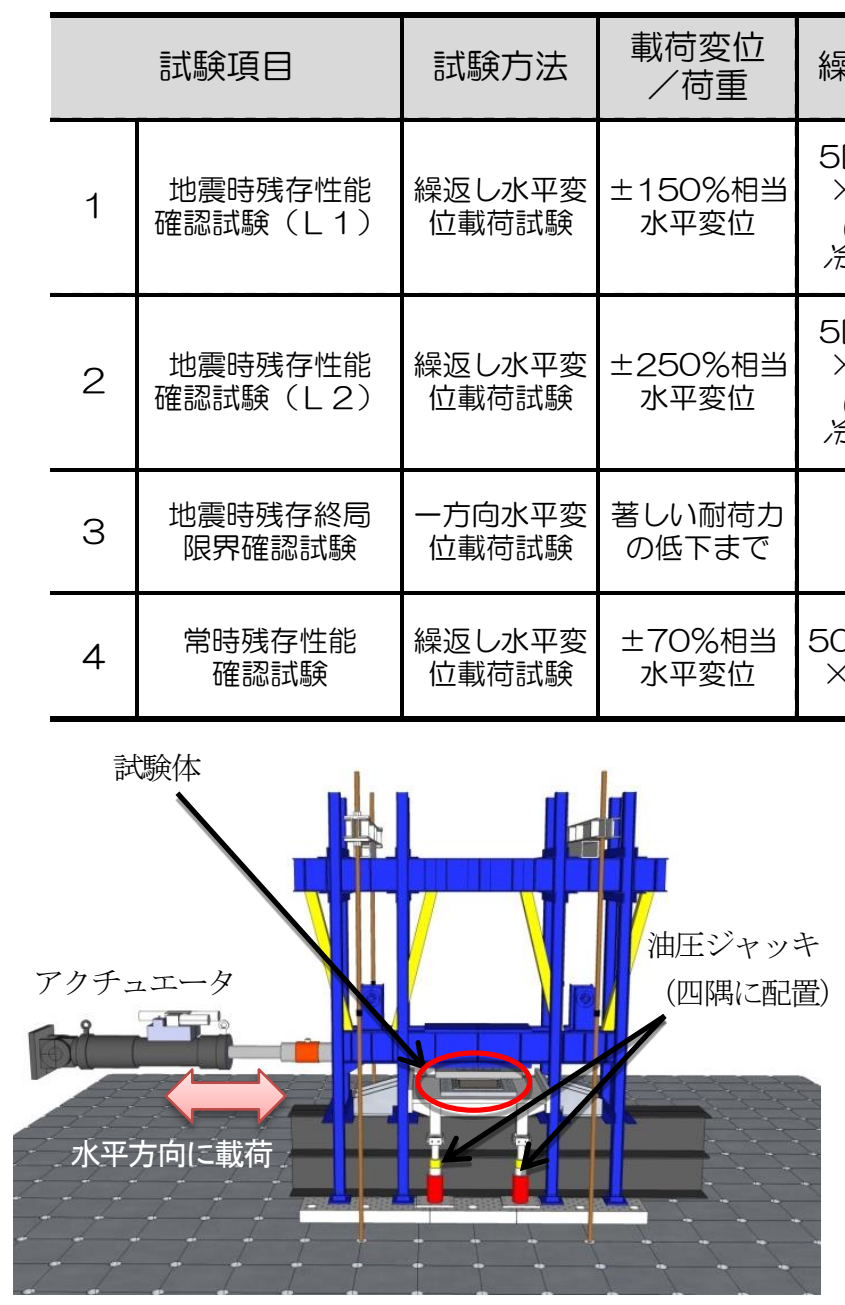

図-5 載荷装置概要図

は劣化支承・リファレンス支承とも各試験で 1 個ずつを あてがっている．常時残存性能確認試験と併せて，以下 に試験概要, 結果ならびに考察を示す.

a）地震時残存性能確認試験（L1）

L1 試験では水平せん断ひずみ $150 \%$ 目標変位とし， 1 セット 5 回の正負交番載荷を合計 3 セット実施した. なお，加力による支承の温度上昇影響をできるだけ排除 するため，セット間で 1 時間の冷却時間を設けた.

3 セット目における履歴曲線の比較を図-6 に示す。 劣化支承の履歴ループが細っており，減衰性能の低 下がうかがえる。表-2 は支承性能パラメータ（等価 剛性 $k_{e q}$, 等価減衰定数 $h_{e q}$ 及び切片荷重 $\left.Q_{d}\right)$ の全セ ットの比較である。等価剛性はリファレンス支承よ り 4〜7\%増加しており，ゴムが硬化していることが 考えられる。また，等価減衰定数及び切片荷重はリ ファレンス支承と比べて半分以下になっていること から，主に鈶プラグの減衰性能が低下したものと考 えられる。参考ながら水平せん断ひずみ $175 \%$ の設 計值と比較すると，等価剛性はやや大きいもののリ ファレンス支承で平均 $+8 \%$ ，劣化支承では+15\%で ある。一方，等価減衰定数はリファレンス支承では 設計值以上だが，劣化支承は大幅に下回っている.

\begin{tabular}{|c|c|c|c|}
\hline \multirow{2}{*}{ 繰返し回数 } & \multirow{2}{*}{ 載荷速度 } & \multicolumn{2}{|c|}{ 性能確認方法 } \\
\hline & & 限界性能 & 閾値 \\
\hline \multirow{2}{*}{$\begin{array}{c}\text { 5回/セット } \\
\times \text { × セット } \\
\text { (セット間 } \\
\text { 冷却1時間) }\end{array}$} & \multirow{2}{*}{ 2～3mm/秒 } & $\begin{array}{l}\text { 著しい変形性 } \\
\text { 能低下まで }\end{array}$ & 3セット以上 \\
\hline & & $\begin{array}{l}\text { エネルギー } \\
\text { 吸収性能 }\end{array}$ & $\begin{array}{c}\text { 著しい低下がな } \\
\text { い }\end{array}$ \\
\hline \multirow{2}{*}{ 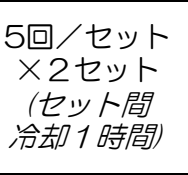 } & \multirow{2}{*}{ 1～2mm/秒 } & $\begin{array}{l}\text { 著しい変形性 } \\
\text { 能低下まで }\end{array}$ & 1セット以上 \\
\hline & & $\begin{array}{l}\text { エネルギー } \\
\text { 吸収性能 }\end{array}$ & 著しい低下がな \\
\hline- & O.5mm/秒 & 最大ひずみ量 & $\begin{array}{l}250 \% \text { 以上 } \\
\text { or } \\
\text { 設計変位以上 }\end{array}$ \\
\hline $\begin{array}{l}\text { 50回／セット } \\
\text { ×50セット }\end{array}$ & O.5mm/秒 & $\begin{array}{c}\text { 著しい変形性 } \\
\text { 能低下まで }\end{array}$ & 50セット以上 \\
\hline
\end{tabular}

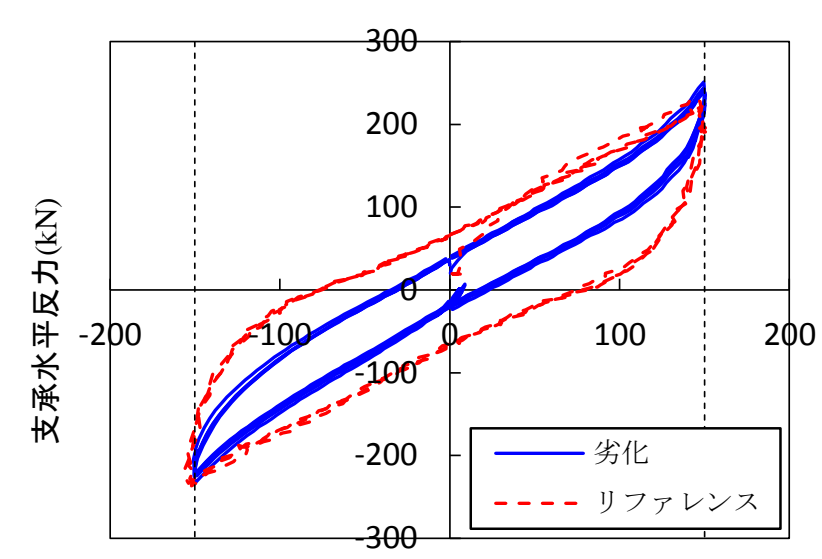

水平せん断ひずみ $(\%)$

図-6 LRB の復元力履歴特性の比較（L1・外 3)

表-2Ｌ１試験における各パラメータ

\begin{tabular}{|c|c|c|c|c|c|c|}
\hline \multirow{2}{*}{$\begin{array}{l}\text { セ } \\
\text { ッ } \\
\text { 卜 }\end{array}$} & \multicolumn{2}{|c|}{$k_{e q}(\mathrm{kN} / \mathrm{mm})$} & \multicolumn{2}{|c|}{$h_{e q}$} & \multicolumn{2}{|c|}{$Q_{d}(\mathrm{kN})$} \\
\hline & $\begin{array}{l}\text { 劣化 } \\
\text { 支承 }\end{array}$ & $\begin{array}{c}\text { リファレソス } \\
\text { 支承 }\end{array}$ & $\begin{array}{l}\text { 劣化 } \\
\text { 支承 }\end{array}$ & $\begin{array}{l}\text { リファレンス } \\
\text { 支承 }\end{array}$ & $\begin{array}{l}\text { 劣化 } \\
\text { 支承 }\end{array}$ & $\begin{array}{l}\text { リファレン } \\
\text { 支承 }\end{array}$ \\
\hline 1 & 2.52 & 2.42 & 0.090 & 0.196 & 33.9 & 69.6 \\
\hline 2 & 2.34 & 2.20 & 0.077 & 0.192 & 29.8 & 66.8 \\
\hline 3 & 2.31 & 2.16 & 0.076 & 0.185 & 29.4 & 66.4 \\
\hline
\end{tabular}

本試験に用いた劣化支承は鉛突出により，製造時 の鈶プラグ量に比べて減少していたことから，その 影響が現れたと言うことができる。しかしながら， 突出によりどの程度減少していたのかは把握できて いないため, 減衰性能の低下と定量的に関連付ける ことは困難である。

また，鈶プラグが減衰性能を発揮するためには， ゴムと鋼鈑から受ける一様な拘束圧のもとで純せん 断となることが必要である.しかしながら, 突出に 伴う鉛量の減少や形状変化によりプラグにかかる拘 束圧が当初より低下かつ不均一となるため, 鉛内部 
で回転が発生し，曲げ変形を受けることが考えられ る.これにより水平方向のせん断変形，すなわち鉛 の塑性変形が抑制され, 期待される減衰レベルに達 しないとも言える.

b）地震時残存性能確認試験（L2）

L2 2試験（目標変位：水平せん断ひずみ $250 \%$ ）もL1試 験と同様に正負交番載荷を行った。 L2地震動は供用中 に発生する確率が低いことから1セット終了後に著しい 変形性能の低下がなければ残存性能を満足することとす るが，性能確認のためさらに1セット追加載荷を行った

両支承の1セット目における復元力履歴特性の比 較を図-7に示す，履歴ループには大きな差異はない が，劣化支承では水平せん断ひずみが $200 \%$ 超え たあたりから荷重が増加していることから，ゴムの ハードニング現象が起きている．表-3に示す各パラ メータの比較より, L1 試験同様, 経年劣化によるゴ ムの硬化と鉛の減衰性能低下が確認される.

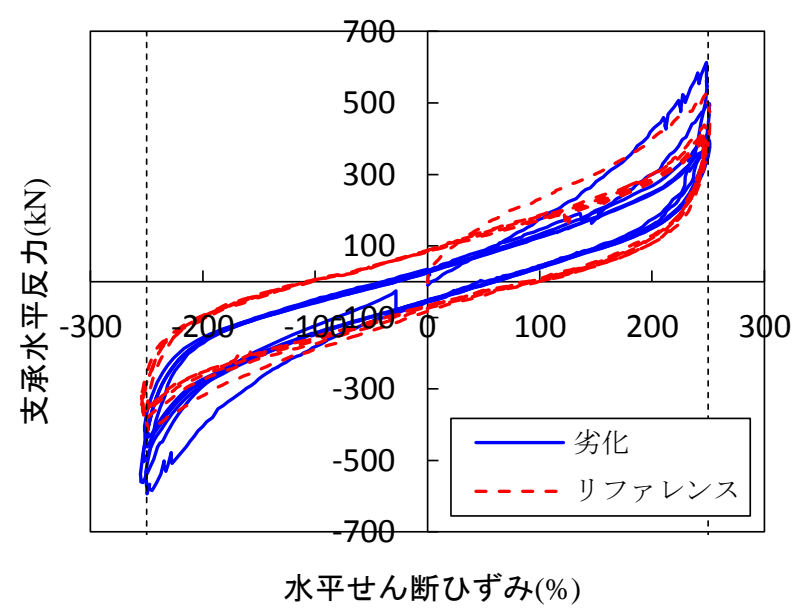

図-7 LRB の復元力履歴特性の比較（L2・卡 1 )

表-3Ｌ２試験における各パラメータ

\begin{tabular}{|c|c|c|c|c|c|c|}
\hline \multirow{2}{*}{$\begin{array}{c}\text { セ } \\
\text { ト }\end{array}$} & \multicolumn{2}{|c|}{$k_{e q}(\mathrm{kN} / \mathrm{mm})$} & \multicolumn{2}{|c|}{$h_{e q}$} & \multicolumn{2}{c|}{$Q_{d}(\mathrm{kN})$} \\
\cline { 2 - 7 } & $\begin{array}{c}\text { 劣化 } \\
\text { 支承 }\end{array}$ & $\begin{array}{c}\text { ⿰ファコンス } \\
\text { 支承 }\end{array}$ & $\begin{array}{c}\text { 劣化 } \\
\text { 支承 }\end{array}$ & $\begin{array}{c}\text { ⿰ファレンス } \\
\text { 支承 }\end{array}$ & $\begin{array}{c}\text { 劣化 } \\
\text { 支承 }\end{array}$ & $\begin{array}{c}\text { リファレンス } \\
\text { 支承 }\end{array}$ \\
\hline 1 & 2.78 & 2.35 & 0.069 & 0.133 & 41.1 & 78.9 \\
\hline 2 & 2.28 & 2.10 & 0.067 & 0.113 & 37.3 & 67.2 \\
\hline
\end{tabular}

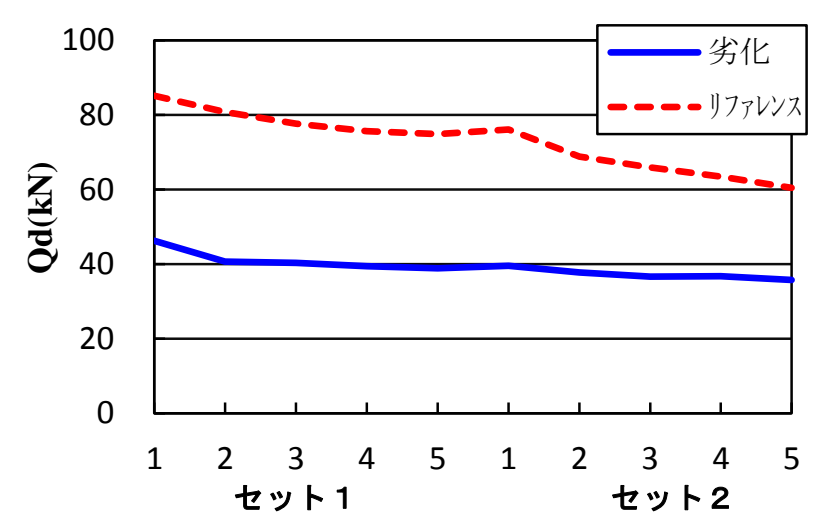

図-8Ｌ2 試験における切片荷重 Qd の推移
また，等価減衰と切片荷重のサイクル毎の変化は, 劣化支承が微減であるのに対し, リファレンス支承 は徐々に低下している（図-8）。これは大変形によ る鉛の変状・抜け出しが生じた可能性がある。

試験後に支承を切断したところ, 写真-5に示すよ うに鉛プラグの破断や側面への飛び出しが確認され ていることから，これが切片荷重の減少と相関する と考えられる.

c）地震時残存終局限界確認試験

終局限界確認試験では試験体の破断もしくは著しい耐 荷力低下まで静的な単調載荷を行った。水平変位は $0.5 \mathrm{~mm} / \mathrm{s}$ の一定速度で漸増させるものとした. 試験で得 られた反力一せん断ひずみ関係を図-9に示す.

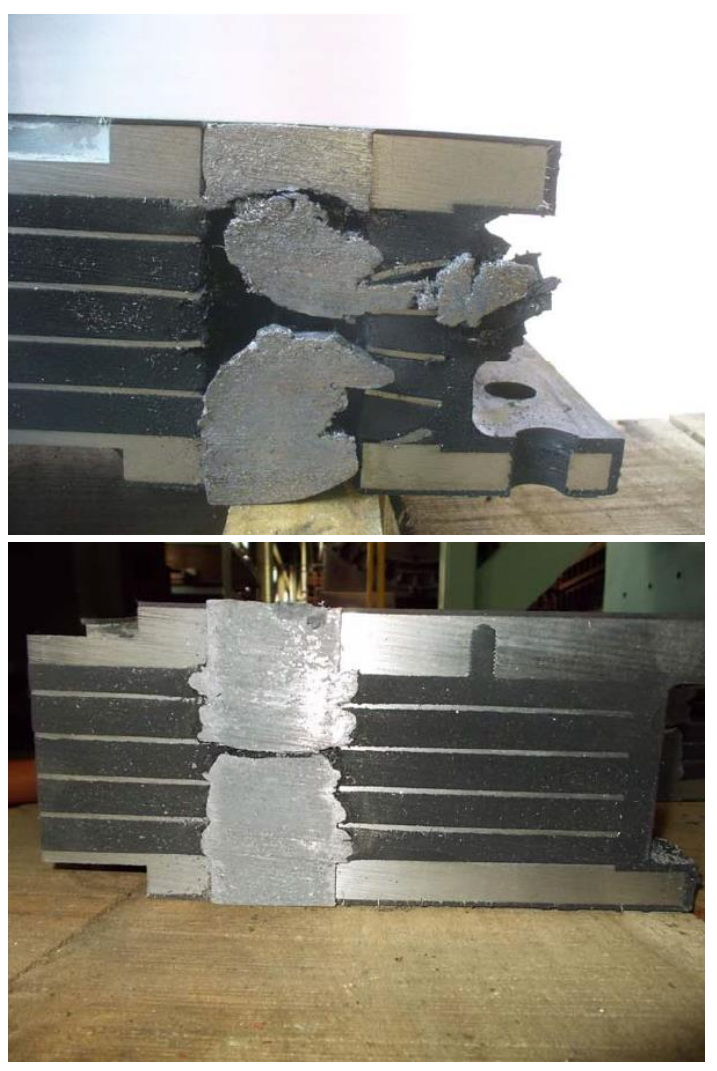

写真-5 L2 試験後のリファレンス支承鉛プラグ状況

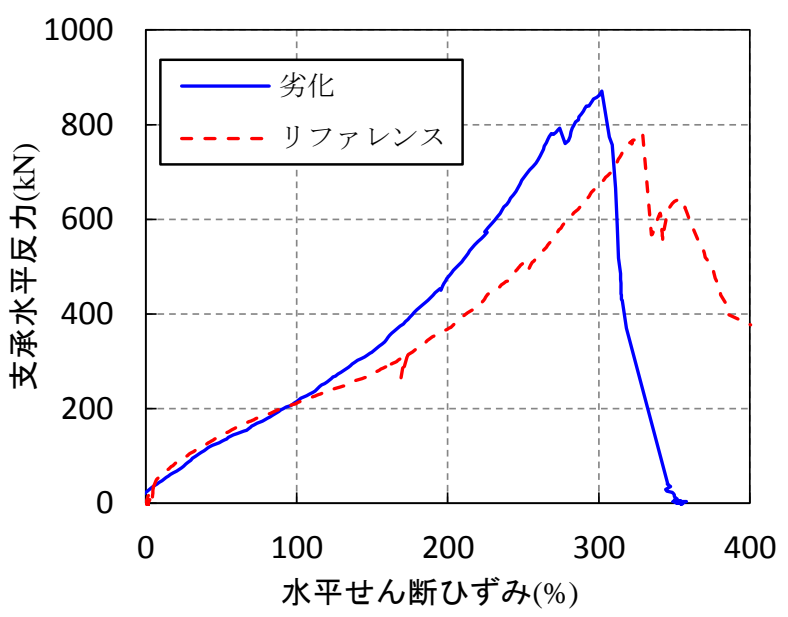

図-9ＬRB の終局限界性能試験の比較 
ゴムの破断の発生時の荷重は両者ともほぼ同じレベル であるのに対し，終局時せん断ひずみは劣化支承の方が やや小さい值となったのは，主に経年劣化によるゴムの 硬化に起因する剛性の増加に起因するものと考えられる. ここで，ゴム体の破断開始時を基準とした終局せん断変 形性能は，劣化支承 $274 \% ，$ リファレンス支承 $329 \%$ あ った（図-9の最初の荷重ピーク值）。両支承ともにL2地 震動のせん断ひずみ許容值である250\%に対する変形性 能は満足していることが判明した。 なお，劣化支承は破 断開始直後にいったん荷重が下がったが，載荷を継続す ると完全破断まで荷重が増加している。これは破断面で の摩擦により回転力が発生したためと考えられる.

写真-6にゴム破断時の状況を示す．位置は異なるが破 断はいずれもゴム層内で生じていた。まず端部が破れ， さらに載荷を続けると破断面が徐々に広がり，その後一 気に全体が断裂した.

\section{d）常時残存性能確認試験}

常時残存性能確認試験として，桁の温度伸縮による支 承変形が及ぼす残存性能を評価することを目的とした低 速繰返しせん断疲労試験に相当する載荷を行った．年間 あたりの桁の温度伸縮による支承変形の累積変形量 $\Delta L$ は式(1)を用いで，累積変形量を常時変形許容ひずみで ある $\pm 70 \%( \pm 49 \mathrm{~mm})$ の繰り返し載荷に対応させる.

$$
\Delta L=\Delta T \alpha l_{m}
$$

$$
\text { ここに, }
$$

$\Delta T:$ 平均日較差であり， $7.35^{\circ} \mathrm{C}$ とする

$\alpha:$ 桁の線膨張係数であり， $12 \times 10^{-6}$ とする ${ }^{9)}$

$l_{m}:$ 伸縮桁長 $149 \mathrm{~m}$

上式から年間の移動量は9,594mmと算出され, これを $\pm 70 \%$ の繰り返し載荷に置換すると, 約 50 サイクルとな る.これを1セットとし, 年間の橋桁の温度伸縮による 常時変形量に相当する変形量とする. 50年間の供用に対 応する50セット以上で著しい性能低下が見られなければ, 供用期間中の残存性能を満足するものとする.

10セットごとの履歴曲線の重ね合わせ比較を図-10に 示す.この結果より復元力特性の著しい変動は見られず, 安定した履歴が得られていることが分かる．また，負側 に荷重が偏っているが，これは初期状態（現地より取り 出した時点）において残留ひずみがあったものと想定さ れる.

図-11は等価剛性と等価減衰定数のセットごとの推移 をプロットしたものであるが，両者とも徐々に低下して いく傾向にある．等価減衰定数は0.094（1セット目）か ら0.083（50セット目）と約1割低下しているが，図-10の 履歴曲線の変化に大きな差異は確認されなかった.つま り常時変形を長期間受けると減衰性能は低下寸るが, 致 命的な影響は受けていないと言うことができる。なお, 等価減衰定数に関しては既往の研究10)により天然ゴムの 常時変形においておよそ5\%であることが分かっており， これより鉛の寄与率は3〜4\%程度であると言える.
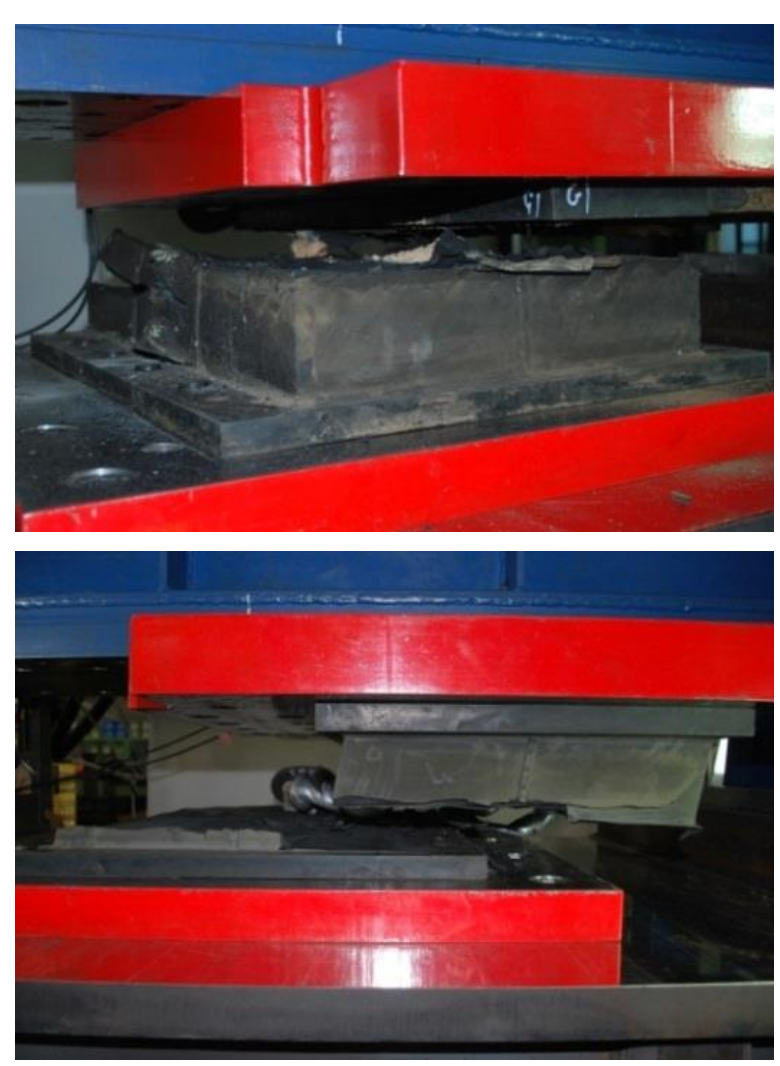

写真-6 破断状況 (上 : 劣化, 下: リファレンス)

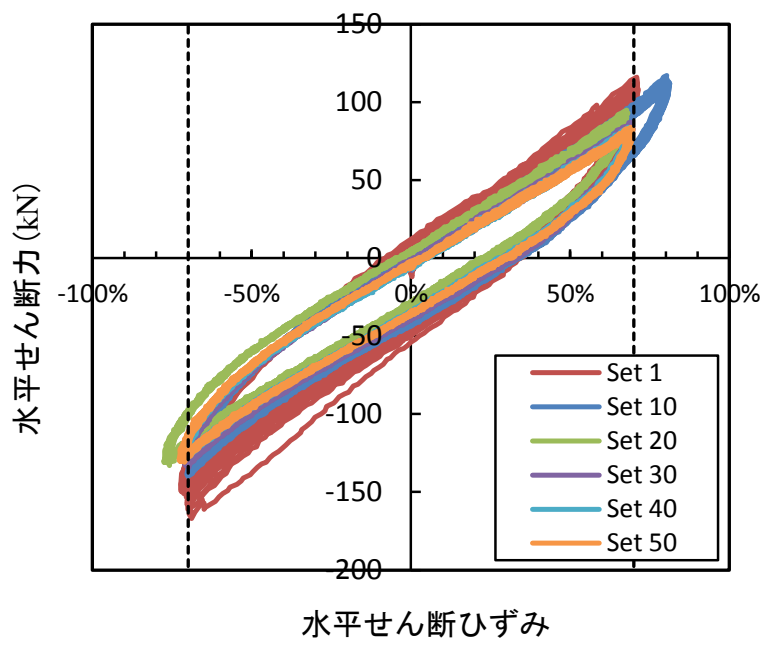

図-10 LRBの常時性能試験における履歴曲線

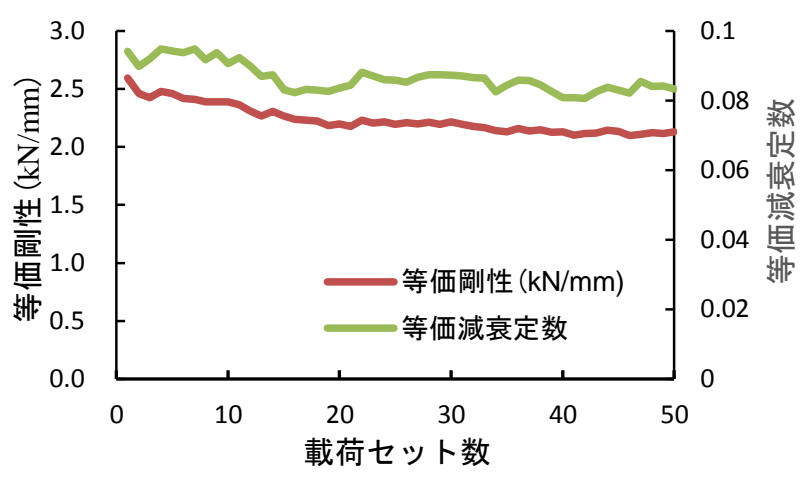

図-11 常時性能試験における支承パラメータの推移 
表-4 材料試験のプロトコル

\begin{tabular}{|c|c|c|c|c|c|}
\hline & \multirow{2}{*}{\multicolumn{2}{|c|}{$\begin{array}{l}\text { 試験番号 } \\
\text { 試験項目 }\end{array}$}} & \multirow{2}{*}{ 測定項目 } & \multicolumn{2}{|c|}{ 性能確認方法 } \\
\hline & & & & 規格値（G8） & JIS規格 \\
\hline \multirow{5}{*}{$\begin{array}{l}\text { 物 } \\
\text { 理 } \\
\text { 試 } \\
\text { 験 }\end{array}$} & \multirow{2}{*}{ (1) } & \multirow{2}{*}{ 引張試験 } & 引張強さ & $15 \mathrm{~N} / \mathrm{mm}^{2}$ 以上 & \multirow{2}{*}{ JIS K 6251} \\
\hline & & & 破断伸び & 550\%以上 & \\
\hline & (2) & せん断変形試験 & 静的せん断弾性係数 & $0.8 \mathrm{~N} / \mathrm{mm}^{2}$ & JIS K 6254 \\
\hline & (3) & 硬さ試験 & JIS硬さ & $50 \pm 5$ & JIS K 6253 \\
\hline & (4) & 接着剂剥離試験 & 接着性能 & $7 \mathrm{~N} / \mathrm{mm}$ 以上 & JIS K 6256 \\
\hline \multirow{2}{*}{$\begin{array}{l}\text { 化学 } \\
\text { 試験 }\end{array}$} & \multirow{2}{*}{ (5) } & \multirow{2}{*}{ 組成分析 } & 老化防止剤残量 & - & JIS K 0123 \\
\hline & & & 溶存酸素量 & - & - \\
\hline
\end{tabular}

\section{(2) 材料試験}

ゴムの物理的及び化学的残存性能の確認を目的として 材料試験を実施した。試験内容を表-4 に示す。これら の項目は共通仕様書 ${ }^{8}$ における天然ゴムの物理的性質と, 支承便覧 ${ }^{1)}$ のゴム材料の特性評価項目に基づき決定した ものである. 性能確認方法として, 各々の規格值を表中 に記載している.

劣化支承及びリファレンス支承より試験片を採取して いるが，表面部と深部との差を確認するために，各々の 支承の図-12に示寸位置から採取した。併せて, 表-4中 の試験番号(1)(2)(4)ついては積層ゴムの層毎の差異を見 るため, 劣化支承の夕図に記載の層からも採取した。 な お，両支承とも前述したL1試験実施後の支承から試験 片を採取する予定であったが，劣化支承においては載荷 試験時トラブルによりL2試験の1セット目途中で載荷中 断した支承を転用している. 以降に試験概要と結果を示 す.

\section{a) 引張試験}

ゴムの機械的強度として, 引張強さ（破断時の最大引 張力を断面積で除した值）と破断時の伸び（破断した時 の伸び比率）を測定した．試験片は橋軸直角方向の面よ り $35 \mathrm{~mm}, 110 \mathrm{~mm}, 230 \mathrm{~mm}$ の位置について，劣化支承は $1 \cdot 2 \cdot 3$ 層目から計9体, リファレンス支承は3層目から 計3体採取し，JIS K 6251に規定されるダンベル状3号型 試験片を作成した。

図-13に引張強さ結果を，図-14に破断伸び結果を示す， 引張強さは全ての試験片で規格值 $15 \mathrm{~N} / \mathrm{mm}^{2}$ 以上が確認さ れたものの，リファレンス支承に比べて劣化支承は7〜 16\%低下している. また，破断伸びにおいてリファレン ス支承では規格值550\%を満足していたが，劣化支承で はほぼ下回る結果となった。製作当時のミルシートでは 破断伸び570\%であることから，それより2１6\%低下し ている. なお，いずれの試験においても表面からの距離 や層毎で明確な差異は認められなかった。

b) せん断変形試験

ゴムの応力ーひずみ特性を求めるための静的せん断弾

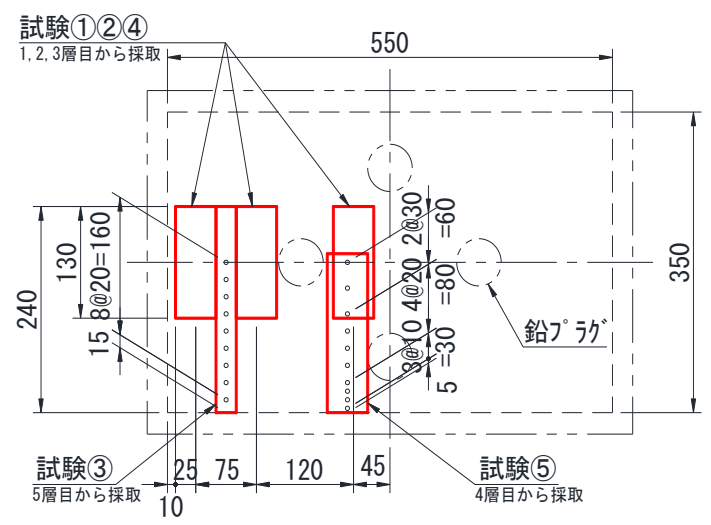

図-12 ゴム試験片の採取平面位置 (劣化支承)

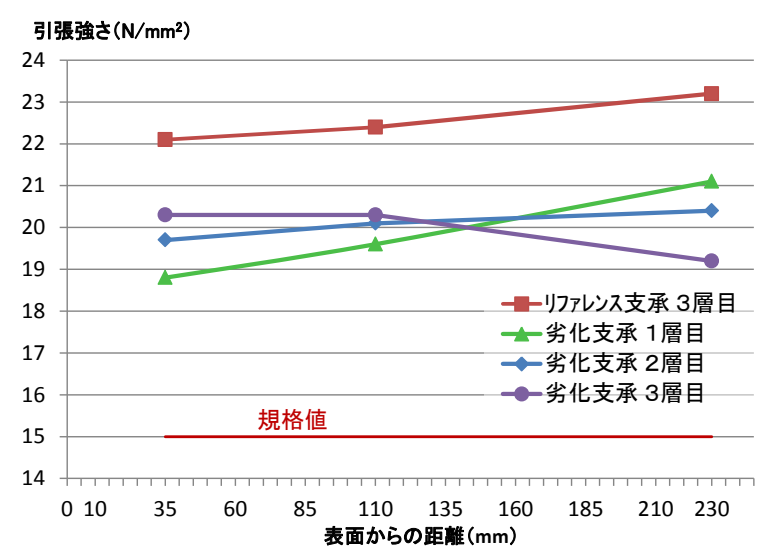

図-13 引張試験（引張強さ）結果

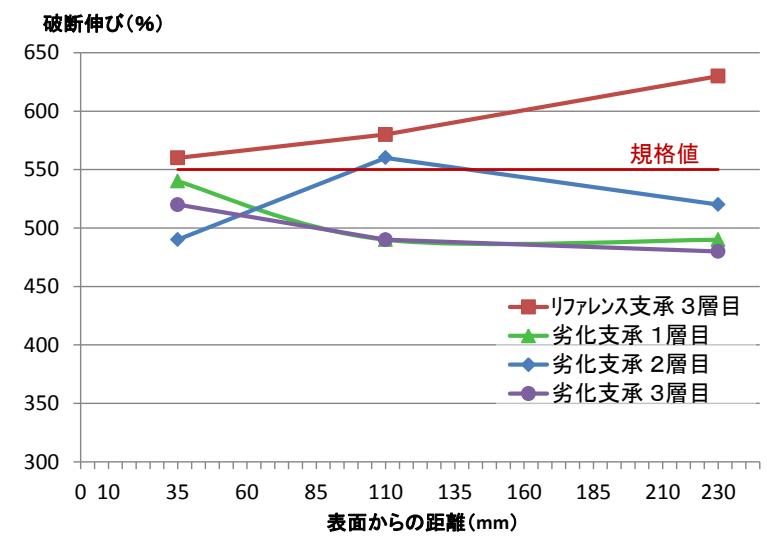

図-14 引張試験（破断伸び）結果 
性率（引張伸びを 25\%与えた場合の弾性率）を測定した。 試験片の採取位置及び数量は引張試験と同じとし，JIS K6254 に規定される短冊状 1 号型試験片を作成した.

測定結果を図-15 に示す。新規製作品に比べ劣化支承 の弾性率が大きくなっている．当該支承のゴムの弾性係 数の呼びは G8 であり $0.8 \mathrm{~N} / \mathrm{mm}^{2}$ が基準となる. リファ レンス支承が基準值に近い（5\%以内）のに対し，劣化 支承は平均で $20 \%$ 程度大きい結果となり，ゴムの硬化が 確認された。 なお，表面からの距離や層毎における傾向 に特段の相関性は見られなかった。

\section{c）硬さ試験}

硬さ試験はデュロメータ試験機（タイプA）を用いて 計測した.ゴム試験片にデュロメータの押針を押しつけ その時に示す抵抗值 (変形量) を0〜100までの数值で示 したものである．橋軸直角方向の面より $72.5 \mathrm{~mm}$ の位置 から $25 \times 240 \mathrm{~mm}$ の試験片を作成し，表面より $15 \mathrm{~mm}$ の深 さを起点に20mmピッチで計9箇所測定した.

図-16に示すとおり，試験值にはバラツキがあるもの

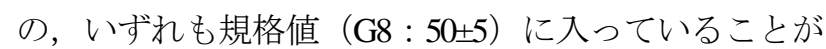
判明した. 一方，リファレンス支承に比心゙劣化支承は硬 い傾向を示した.これは経年劣化によるゴムの硬化とお よ之一致するものと考えられる。 また，表面からの距離 による影響は明確ではない.

\section{d）接着剂はく離試験}

ゴムと鋼板の接着強さは，ゴム支承本体の耐荷力・耐 久性に影響するものであり，その評価としてJIS K 6256 に規定される90度はく離試験を実施した。

いずれの試験においても接着層ではく離したものはな く，ゴムで破断する結果となった。 はく離強さは図-17 に示すとおり，一部で規格值（7 N/mm以上）を下回る ものもあるが，接着層でのはく離ではないことを考慮す ると, 接着強さは満足しているとみなすことができる.

また，劣化支承の強度が高い傾向であることから，ゴム の硬化が影響しているものと考えられる.

なお，JIS規定では鋼板にゴムを接着させた試験片を 使用するのに対し，今回のように既存積層ゴムから取り 出して製作する試験片は，鋼板とゴムの境界付近をカッ ターで切断したものとなるため，そのことが影響してい ると考えられる.

\section{e）組成分析 (老化防止剂残量) 試験}

ゴムの劣化を抑制する目的で老化防止剤が配合されて いるが，経年によるその変化（残量）と分布を確認する 試験を実施した。試験方法はJIS K 0123に規定されるガ スクロマトグラフ質量分析器を用いて計測した.

リファレンス支承の最深部（表面より175mmの位置） の残存量を $100 \%$ とした場合の各測定箇所の割合を図-18

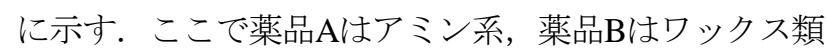
である.アミン系老化防止剤は而熱性，耐オゾンき裂性，

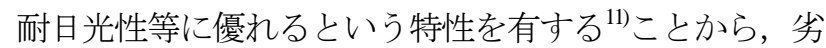
化支承において表面に近いほど消費されて残量が少なく なっている傾向が確認された。 一方，ワックス類はアミ ン系と併用すると耐オゾン性が向上し，表面き裂を防

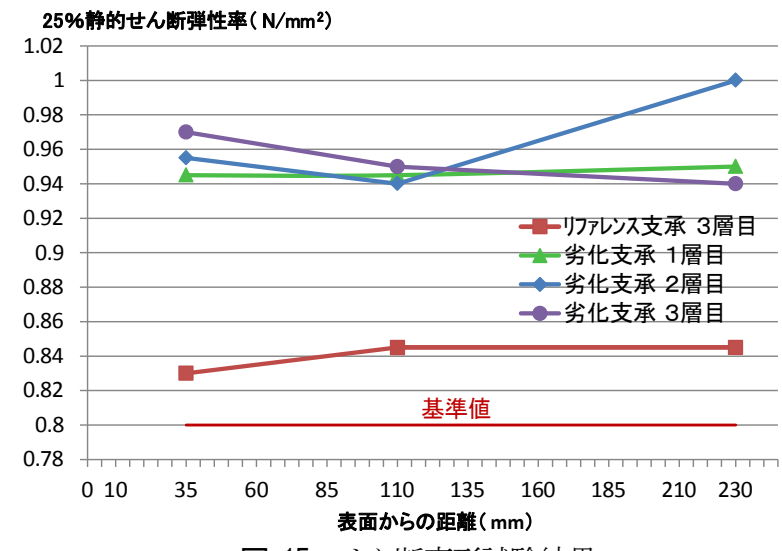

図-15 せん断変形試験結果

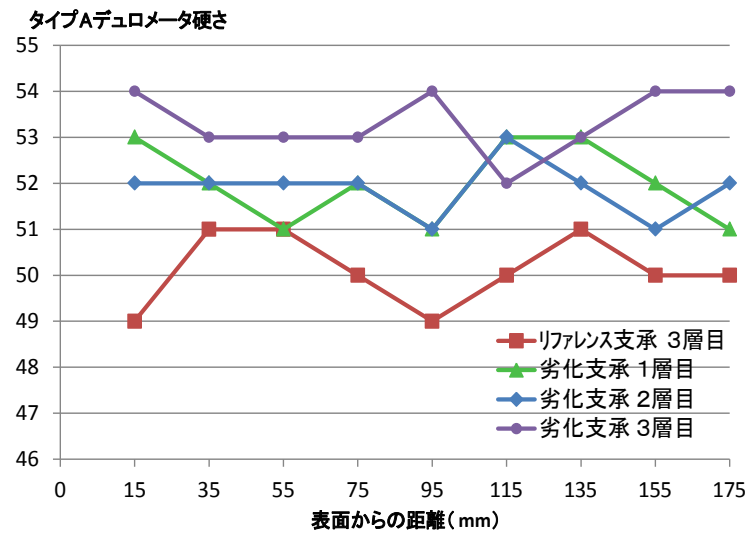

図-16 硬さ試験結果

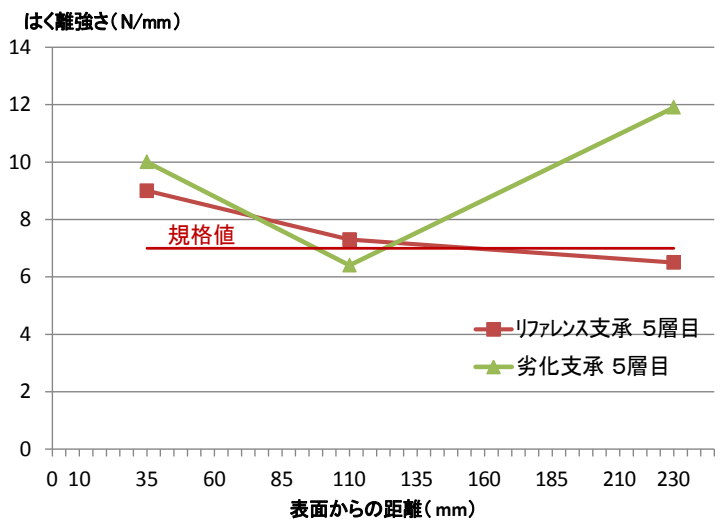

図-17 接着剂はく離試験結果

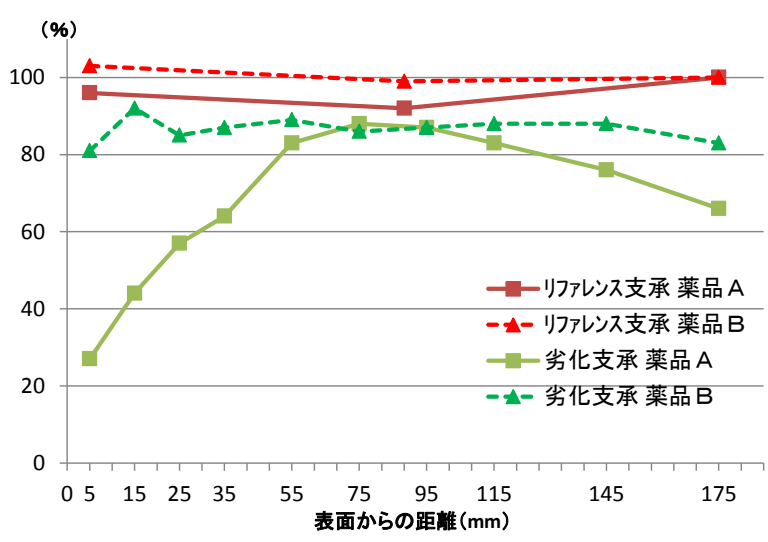

図-18 組成分析（老化防止剂残量）結果 
止する効果がある ${ }^{12}$ が，本試験では幾分か消費されてい るものの, 表面からの深さ方向で明確な変化は確認され なかった。

\section{f）組成分析（溶存酸素量）試験}

ゴムの劣化は空気中のオゾンによる酸化劣化が主要因 の一つであるため ${ }^{2}$ ，ゴムの溶存酸素量を元素分析装置 にて計測した．結果を図-19に示寸，リファレンス支承 は表面からの距離によらずほぼ一定值を示すのに対し， 劣化支承はバラツキがあるものの表面付近で高い溶存酸 素の傾向が確認された. このことから，表面に近いほど オゾン劣化の発生確率が高いことがうかがえる.

\section{(3) 目視観察}

力学試験後のゴム支承の外観及び切断面観察を実施し た. 写真-7に外面及び切断後の内部状況の一例を示 寸。外面は特段目立った変化は確認できなかった（当 初の損傷を除く）が，切断後の内部状況は鉛の変形によ りプラグ孔に空隙が生じ，一部は鉛がゴムへ押し出され ゴムと鋼板との接着面が剥離した状態にあった．併せ て鉛プラグの割れが生じていることや土状の紛体の 付着も確認された.

このような状況に至ったメカニズムは現時点では 未解明だが, 供用中 (常時) や載荷試験時の変形, あるいは何らか劣化因子の浸入が影響しているもの と考えられる。

\section{6. 結言}

鉛プラグの突出が見られた経年劣化損傷LRBの保有性 能を水平載荷による力学試験及び材料試験により確認す るとともに，各々リファレンス支承との比較により残存 性能の検証を行った. これらにより得られた知見をまと めると, 以下のとおりである.

○劣化支承とリファレンス支承との比較から, 経年 劣化によるゴムの硬化により剛性が増加している ものと推定される.

等価減衰定数及び切片荷重の比較より, 減衰性能 が低下している傾向が見られる.この主要因とし ては鉛プラグの劣化もしくは突出による鉛総量の 減少による影響が考えられる。

○終局限界試験におけるゴム破断時の水平荷重は両 支承で大きな差異はないが，水平せん断ひずみは 劣化による影響が少なからず現れている。しかし ながら, 変形性能は確保されていると言える.

$\bigcirc$ 常時残存性能については, 50 年相当の載荷による 復元力特性の著しい変動は見られず安定な挙動が 得られている.

常時性能及び変形性能に関しては特段の問題はないと 考えられる. ただし，リファレンス支承は当時の材料表 に基づき再現製作しているが，製造方法の完全再現まで

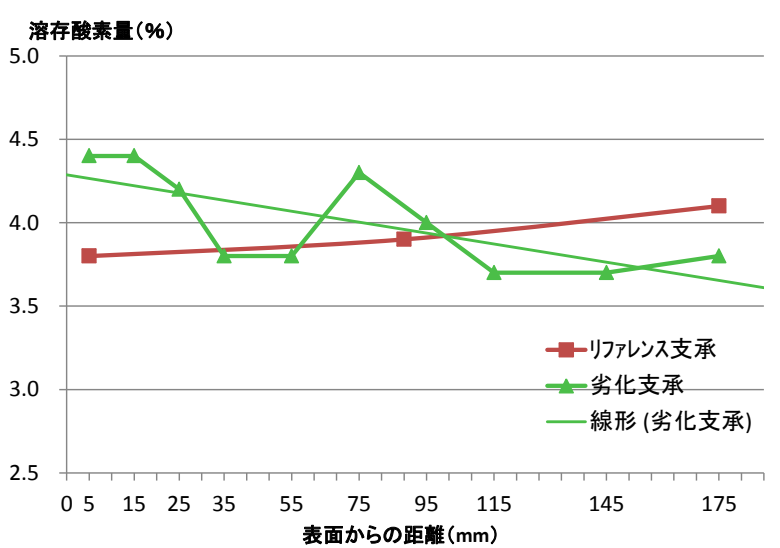

図-19 組成分析 (溶存酸素量) 結果
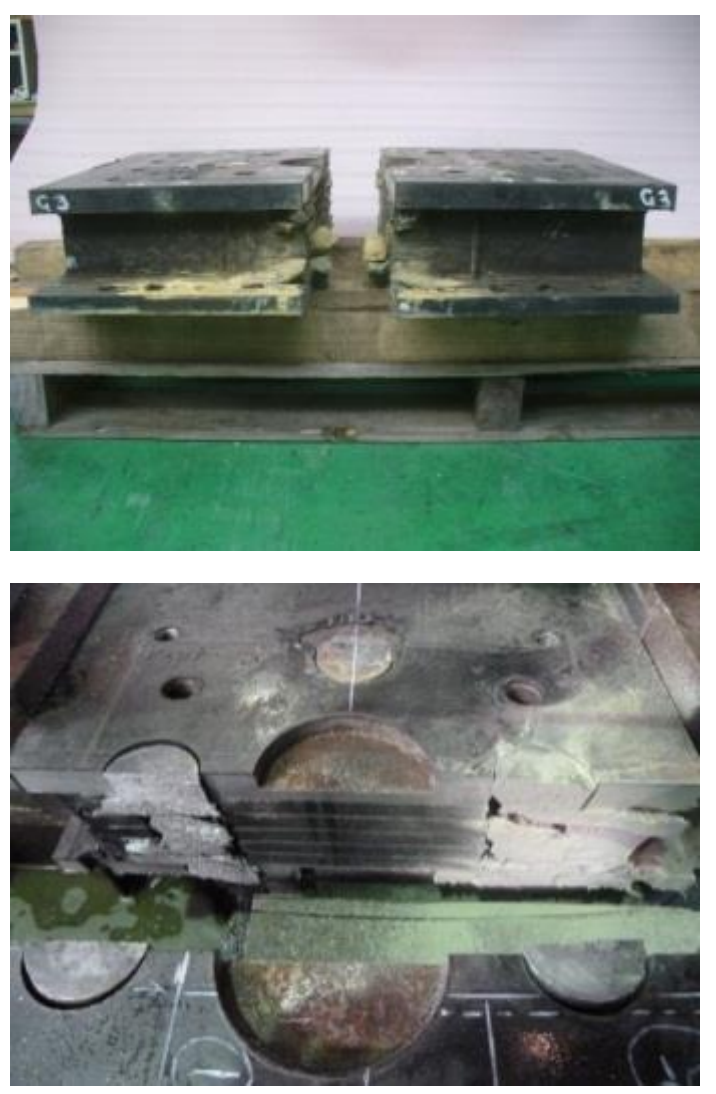

写真-7 支承外面（上）及び内部状況（下）

は困難であることから，試験結果は参考值と考えること とする. そのため, 地震時残存性能については直ちに結 論を導くことは困難なため, 並行して実施している解析 と併せて, より詳細に評価する必要がある.

なお，目視観察において鉛プラグの変状が顕著であっ た. 鉛の突出損傷と併せて, 減衰性能の低下に影響して いる可能性が考えられることから，今後はこちらにも着 目し調查することが望ましい.

謝辞 : 本論文執筆にあたり, 愛知工業大学耐震実験セン ター長・青木徹彦教授（当時, 現愛知工業大学名誉教授） には載荷装置使用において多大な協力をいただいた。こ こに深く感謝致します。 


\section{参考文献}

1）（社）日本道路協会 : 道路橋支承便覧，丸善，2004

2) 伊藤義人，矢澤晃夫，佐藤和也，顧浩声，忽那幸浩，山本 吉久 : 橋梁支承用ゴムの環境劣化特性に関する基礎的研究, 土木学会論文集 No.794／I-72，pp.253-266，2005.

3) 阿波根朝浩 : ゴムの疲労破壊, 日本ゴム協会誌第75巻第6 号, pp.246-251, 2002.

4) 土木学会地震工学委員会 : 第15回性能に基づく橋梁等の耐 震設計に関するシンポジウム 東日本大震災による橋梁等 の被害分析WG報告書, pp.II46-51，2012.

5）曽田信雄，山田金喜，木水隆夫，広瀬剛，鈴木基行 : 東 北地方太平洋沖地震により破断した積層ゴム支承の 性能試験, 構造工学論文集 Vol.59A, pp.516-526, 2013.

6) 伊藤義人, 佐藤和也, 顧浩声, 山本吉久 : 橋梁用天然ゴム 支承の性能劣化特性に関する研究, 土木学会論文集A,
Vol.62, No.2, pp.255-266, 2006.

7) 国土交通省国土技術政策総合研究所 - 独立行政法人建築研 究所 : 平成23年 (2011年) 東北地方太平洋沖地震被害調查 報告，国総研資料第674号／建築研究資料第136号， 2012.

8）阪神高速道路株式会社：土木工事共通仕様書，2009.

9）（社）日本道路協会 : 道路橋示方書 I 共通編，丸善，2012. 10) 鵜野禎史, 森重行雄, 今井隆, 竹之内勇 : 天然ゴム系ゴ ム支承のせん断変形性能, 第2回免震・制震コロキウ ム講演論文集, pp.143-148, 2000.

11) 久保田威夫, 栗林愿 : ゴムの老化防止剤について, 有機合 成化学第13巻第11号, pp.33-39, 1955.

12) 安藤慎二, 深町真治 : 老化防止剤, 日本ゴム協会誌第82巻 第2号, pp.45-49, 2009.

(2013.11. 15 受付, 2014.2.11 修正, 2014.2.22 受理)

\section{EXPERIMANTAL VERIFICATION FOR REMAINING PERFORMANCE OF LEAD RUBBER BEARINGS WITH AGING DETERIORATION}

\section{Kunihiro HAYASHI, Yukio ADACHI, Katsuaki KOMOTO, Hitoshi YATSUMOTO, Akira IGARASHI, Ji DANG and Tomohiro HIGASHIDE}

Since Hyogo-ken Nanbu Earthquake in 1995, many laminated rubber bearings have been installed because of horizontal force dispersion or seismic isolated design. Although some rubber bearings with long period in service are reported several damages caused by aged deterioration, it is not clear about the bearing performance and most damaged bearings are remained as it is. In this study, the authors carried out the load test and the material test using some aging deterioration damaged lead rubber bearings, in order to verify the remaining performance. As a result, it turned out that the bearing stiffness was increased and seismic damping performance was reduced caused by aging deterioration of natural rubber and lead. 